Acta Universitatis Lodziensis

\title{
The use of in vitro assays for the assessment of cytotoxicity on the example of MTT test
}

\author{
Magdalena TwaruŻeK*, Ewa ZastempowsKa, Ewelina SoszczyńsKa, IwONA \\ AŁTYN
}

Department of Physiology and Toxicology, Institute of Experimental Biology, Faculty of Natural Sciences, Kazimierz Wielki University, Chodkiewicza 30, 85-064 Bydgoszcz, Poland

E-mail: twarmag@ukw.edu.pl

\begin{abstract}
In recent years, biological tests have been developed based on cell cultures and successfully used to the hygienic assess of a variety of samples. In vitro assays become the complement of conventional chemical methods. They do not narrow the results only to the quantitative and qualitative information on toxic substances, but also increase knowledge on the direct impact on the organism. They are also an alternative for animal testing, which are currently given up for ethical reasons. At present, the market is steadily increasing in the number of tests and bio-assay techniques. Based on our own studies we conclude that the MTT test is perfect as a diagnostic method for evaluating the cytotoxicity of materials of different composition such as mycotoxins, pesticides, bacterial cultures, moulds isolates, food, feed, as well as a vast spectrum of other environmental samples.
\end{abstract}

KEY WORDS: MTT test, SK cells, cytotoxicity

\section{Introduction}

Due to the significant development of industry, a lot of harmful substances are released into the water, air, soil, and to our bodies, which contributes significantly to the development of environmental toxicology. Interests in issues of xenobiotics and compounds interfering the proper functioning of cells and organisms as a result of a number of their toxic effects has increased. An increase in exposure of humans and animals through food additives, to the industrial toxins or secondary fungal metabolites, has been observed. The exposure became a major problem in laboratory diagnostics. Therefore, it is important to develop rapid and cost-effective in vitro assays for identification of potentially toxic substances. The possible impact of new and existing chemical substances has led to the development of a wide range of methods for testing their biological effects. Methods for toxicity evaluating using cellular models (in vitro) have 
become an alternative for tests performed on animals. They are relatively simple and easy to make, while increasing their accuracy and sensitivity. They now constitute the basis for determining safe levels of chemical compounds, thus constantly increasing the information database concerning degree of toxin harmfulness. It should be remembered that the use of animals for biological tests is costly, time consuming, and often relates to ethical issues. Therefore, the Committee of Toxicology and Environmental Factors Assessment of US National Research (NRC) undertakes the initiative to develop the non-invasive in vitro tests and computer methods based on human biology in order to prevent the reaction evaluations based on groups of animals. It is also postulated the use of cells and change of paradigm of carrying out the experiments on animals towards the in vitro direction (Sikorski \& Adomas 2010).

Cytotoxicity is one of the basic mechanisms of the evaluation of toxic substances. To determine the in vitro cytotoxic activity multiple techniques for measuring changes related to a disturbance of physiological processes within human or animal cells caused by the test substance, are applied. Tests used to evaluate the cytotoxicity allow for a direct or indirect measurement of different changes reflecting the cytotoxic activity, e.g. number of live and dead cells, sometimes, in combination with determination of the cell membrane integrity, assay the enzyme activity related to cell metabolism, determining the ability to cell division, or determination of the total protein or DNA in the cell culture (Krzysztoń-Russjan et al. 2009).

\section{Some of the tests and techniques for bio-assays}

Depending on the method used, cytotoxicity testing can be divided into two groups. One type of tests measures the total protein content, which include, among others, Kenacid Blue test and sulforhodamine B staining. The second group of tests is based on methods based on measurements of redox activity. That group includes Alamar Blue assay, XTT test, and MTT test.

Kenacid Blue test allows to determine the overall amount of cellular protein measured by its fast coloration. The amount of pigment incorporated into the cell culture determines the degree of cytotoxicity caused by the test agent (Putnam 2002).

Sulforhodamine B staining also allows the measurement of the total protein content within the cell, on the basis of which the cytotoxic activity is determined. Sulforhodamine $B$ is a pigment that is bound to the basic amino acids of cellular proteins. The amount of protein in the sample is directly proportional to the number of living cells (Anuszewska 2010).

One of the fundamental and rapid tests by means of living cells measuring is neutral red uptake by lysosomes. This pigment passes through the cell membrane of living cells only and accumulates in the lysosomes. This test distinguishes living and undamaged from dead cells by determining the number of viable cells stained red (Stokłosowa 2004).

LDH test is a method based on enzymatic reactions resulting in a colored by-product determined by spectrophotometry. Lactic dehydrogenase (LDH) is a cytosolic enzyme, which under physiological conditions is not released into the environment. Mechanical damage of the plasma membrane and the cell death caused by the action of harmful factors, invokes the release of LDH from cells (Szliszka et al. 2007). The enzymatic reactions in the assay take place in two stages: first, lactate is converted to pyruvate (LDH catalyzes the reaction), 
whereas during the second stage, diaforase catalyzes the transfer of $\mathrm{H}^{+}$onto tetrazoline that is reduced to formazan. Currently, the LDH level is used as a general indicator of the presence and severity of acute or chronic tissue damage (Hak 2006).

Example of another test indicating a lack of cell membranes integrity is the NAG test. It allows for the demonstration of the lysosomal enzyme N-acetyl-betaD-glucosaminidase presence in a culture medium, which is possible only when the cells are damaged (Krzysztoń-Russjan et al. 2009).

Acridine orange stain is versatile and most widely used to distinguish live cells from apoptotic and necrotic ones. The assay utilizes the ability of pigment passing through the cell membrane, due to which it colors the whole cell. Fixed as compared to the live cells vary in cytoplasm and nucleoli color. This is because cell membrane is damaged during the fixing process, and thereby rapid inflow and accumulation of the pigment inside the cells is enabled (Noatyńska 2011).
Alamar Blue assay uses the natural metabolic processes in cells. Alamar Blue is stable and non-toxic compound and contains the oxidation-reduction indicator (redox). When it is oxidized, turns blue (and it is weakly fluorescent then), while after placing this compound in living cells, gets reduced and turns red. The size of this change is a reflection of cell viability (Nakayama et al. 1997).

XTT assay is one of colorimetric methods, which are based on the reduction of pigmented indicator added to the growth medium. The method uses the process of XTT tetrazoline ring cleavage involving mitochondrial dehydrogenases of living cells, leading to the formation of orange formazan molecules. The rate of reduced formazan formation is proportional to the number of living cells (Dzierżewicz et al. 2005, Sajduda 2007).

The MTT test is a quantitative colorimetric test for toxicity, which is based on conversion of yellow-colored tetrazolium salt (MTT) into violetcolored, water-insoluble formazan (Fig. 1). This reduction occurs proportional, as only living cells have such ability.

Figure 1. Reduction of MTT to formazan (Stokłosowa 2004, p. 251).

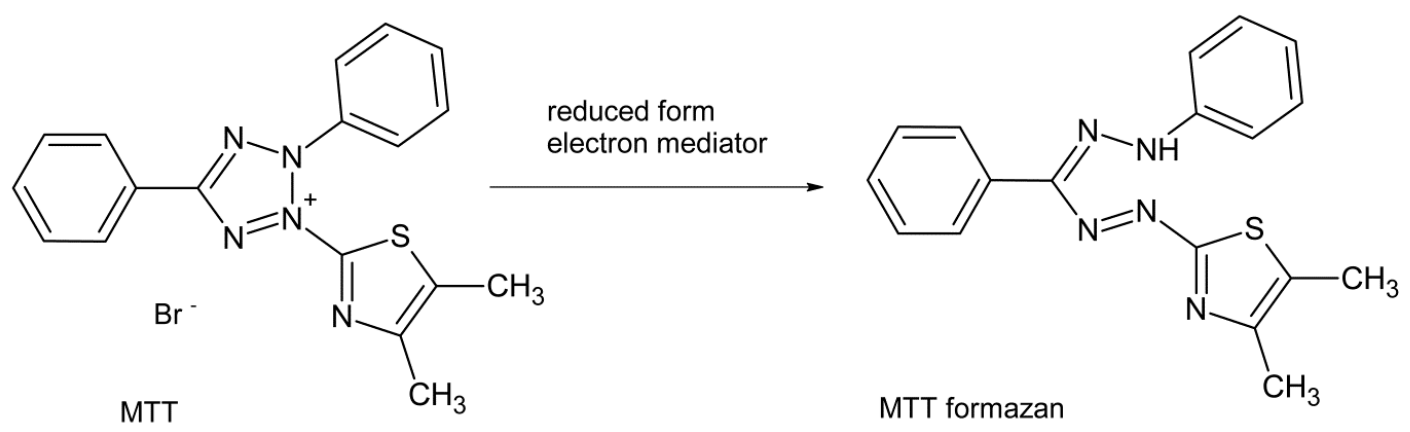

This test was developed in the 80 's by Mosmann and is one of the most commonly used methods for rapid, quantitative assessment of sample cytotoxicity against cells (screening method). It gives no information on the type of occurring toxins, but their biological effects in the form of cytotoxicity (Hanelt et al. 1994). 
Cellular MTT bio-reaction is associated with enzymes of the endoplasmic reticulum and affects the reduction of pyridine. Only metabolically active cells carry out this process. Thus, if cells have previously been damaged or destroyed by a toxin, the reaction is less intense or does not occur at all, which can be determined due to the change of color and photometric determination. Full analysis involves the sample testing (contaminated or potentially contaminated material) and control (pure material) as a reference for the cytotoxicity assessment, because this test can detect, e.g. in addition to the contamination with mycotoxin, also other causes of cytotoxicity, as well as those causing a range of allergic reactions (Grajewski \& Twarużek 2004).

Due to the fact that the cell culture test (MTT) is characterized by a high sensitivity and is a quick tool for evaluation of cytotoxicity, it can be used to test a large number of samples (Woźniak et al. 2004). Gareis (2006) reports that the colorimetric MTT test can be used as a diagnostic means for evaluating the cytotoxicity of materials of different composition, i.e. mycotoxins, pesticides, mould isolates, bacterial cultures, foods, feeds, as well as environmental samples. In 1999, Gareis with Kuss demonstrated the usefulness of the MTT test for the analysis of organic and inorganic compounds, that often charge the foodstuffs, posing a risk to the consumer. In general, this test was useful to demonstrate the traces of pesticide residues - not only to indicate the insecticides, but also less toxic herbicides, fungicides, or growth regulators. Among tested plant protection means, for up to 24 of 28 , they found the decrease in vitality of cells by $10 \%$, while for the half of substances they observed the drop in cell vitality by $50 \%$. They also studied selected systems of these xenobiotics combinations. Of the 6 analyzed ones, 2 mixtures showed an independent activity, while the remaining 4 were characterized in part by synergistic effect. There was no antagonism. Our own findings suggest that the MTT test is useful for determining the cytotoxicity of bacterial strains pathogenic to humans and animals (Zastempowska \& Twarużek, 2016).

\section{The principles of MTT test}

Properly prepared extracts are placed in the wells of the pre-dilutions plate (96well plate) according to the protocol for test samples distribution. Most often, three extracts in horizontal distribution in a suitable number of dilution -10 , are tested at one micro-plate (Fig. 2). The highest and the lowest rows constitute a cellular barrier and the first column is left free as a zero value for the reader. Released cells brought into the suspension state with a precise indication of their quantity are added to the second plate (test plate). They are transferred to all wells of the plate leaving only the first column free. Such prepared plates are placed in an incubator $\left(37^{\circ} \mathrm{C}, 5 \% \mathrm{CO}_{2}, 98 \%\right.$ humidity $)$ for 48 hours. After this time, the inspection of cells growth is carried out under inverted microscope and MTT salt solution is prepared. A sterile salt is added to the wells and plate is re-incubated for 4 hrs. Then the entire contents of the wells is pulled off using vacuum pump and DMSO is added to each well.

Wells to control the cells are dark purple and correspond to $100 \%$ of the division activity. Wells containing contaminated (cytotoxic) sample are discolored, or their color is much less intense (Fig. 3). The absorption values of samples less than $50 \%$ of the division activity are considered to be toxic. Based on the degree of dilution, the limit toxic concentration can be determined, i.e. the lowest tested sample that caused the toxic effects to cells. 
Figure 2. Scheme of extracts distribution on testing plate.

$\mathrm{E}-$ dissolved extract, e - diluted extract, S+K - SMEM (special medium) with cells.

\begin{tabular}{|c|c|c|c|c|c|c|c|c|c|c|c|c|}
\hline & 1 & 2 & 3 & 4 & 5 & 6 & 7 & 8 & 9 & 10 & 11 & 12 \\
\hline \multicolumn{13}{|l|}{ A } \\
\hline B & & & $\mathrm{E}$ & $\begin{array}{l}E \\
S+K\end{array}$ & $\begin{array}{l}\mathrm{e} \\
\mathrm{S}+\mathrm{K}\end{array}$ & $\begin{array}{l}\mathrm{e} \\
\mathrm{S}+\mathrm{K}\end{array}$ & $\begin{array}{l}\mathrm{e} \\
\mathrm{S}+\mathrm{K}\end{array}$ & $\begin{array}{l}\mathrm{e} \\
\mathrm{S}+\mathrm{K}\end{array}$ & $\begin{array}{l}\mathrm{e} \\
\mathrm{S}+\mathrm{K}\end{array}$ & $\begin{array}{l}\mathrm{e} \\
\mathrm{S}+\mathrm{K}\end{array}$ & $\begin{array}{l}\mathrm{e} \\
\mathrm{S}+\mathrm{K}\end{array}$ & $\begin{array}{l}\mathrm{e} \\
\mathrm{S}+\mathrm{K}\end{array}$ \\
\hline $\mathrm{C}$ & & & $\mathrm{E}$ & $\begin{array}{l}E \\
S+K\end{array}$ & $\begin{array}{l}\mathrm{e} \\
\mathrm{S}+\mathrm{K}\end{array}$ & $\begin{array}{l}\mathrm{e} \\
\mathrm{S}+\mathrm{K}\end{array}$ & $\begin{array}{l}\mathrm{e} \\
\mathrm{S}+\mathrm{K}\end{array}$ & $\begin{array}{l}\mathrm{e} \\
\mathrm{S}+\mathrm{K}\end{array}$ & $\begin{array}{l}\mathrm{e} \\
\mathrm{S}+\mathrm{K}\end{array}$ & $\begin{array}{l}\mathrm{e} \\
\mathrm{S}+\mathrm{K}\end{array}$ & $\begin{array}{l}\mathrm{e} \\
\mathrm{S}+\mathrm{K}\end{array}$ & $\begin{array}{l}\mathrm{e} \\
\mathrm{S}+\mathrm{K}\end{array}$ \\
\hline $\mathrm{D}$ & & & $\mathrm{E}$ & $\begin{array}{l}E \\
S+K\end{array}$ & $\begin{array}{l}\mathrm{e} \\
\mathrm{S}+\mathrm{K}\end{array}$ & $\begin{array}{l}\mathrm{e} \\
\mathrm{S}+\mathrm{K}\end{array}$ & $\begin{array}{l}\mathrm{e} \\
\mathrm{S}+\mathrm{K}\end{array}$ & $\begin{array}{l}\mathrm{e} \\
\mathrm{S}+\mathrm{K}\end{array}$ & $\begin{array}{l}\mathrm{e} \\
\mathrm{S}+\mathrm{K}\end{array}$ & $\begin{array}{l}\mathrm{e} \\
\mathrm{S}+\mathrm{K}\end{array}$ & $\begin{array}{l}\mathrm{e} \\
\mathrm{S}+\mathrm{K}\end{array}$ & $\begin{array}{l}\mathrm{e} \\
\mathrm{S}+\mathrm{K}\end{array}$ \\
\hline $\mathrm{E}$ & & & $\mathrm{E}$ & $\begin{array}{l}\mathrm{E} \\
\mathrm{S}+\mathrm{K}\end{array}$ & $\begin{array}{l}\mathrm{e} \\
\mathrm{S}+\mathrm{K}\end{array}$ & $\begin{array}{l}\mathrm{e} \\
\mathrm{S}+\mathrm{K}\end{array}$ & $\begin{array}{l}\mathrm{e} \\
\mathrm{S}+\mathrm{K}\end{array}$ & $\begin{array}{l}\mathrm{e} \\
\mathrm{S}+\mathrm{K}\end{array}$ & $\begin{array}{l}\mathrm{e} \\
\mathrm{S}+\mathrm{K}\end{array}$ & $\begin{array}{l}\mathrm{e} \\
\mathrm{S}+\mathrm{K}\end{array}$ & $\begin{array}{l}\mathrm{e} \\
\mathrm{S}+\mathrm{K}\end{array}$ & $\begin{array}{l}\mathrm{e} \\
\mathrm{S}+\mathrm{K}\end{array}$ \\
\hline $\mathrm{F}$ & & & $\mathrm{E}$ & $\begin{array}{l}E \\
S+K\end{array}$ & $\begin{array}{l}\mathrm{e} \\
\mathrm{S}+\mathrm{K}\end{array}$ & $\begin{array}{l}\mathrm{e} \\
\mathrm{S}+\mathrm{K}\end{array}$ & $\begin{array}{l}\mathrm{e} \\
\mathrm{S}+\mathrm{K}\end{array}$ & $\begin{array}{l}\mathrm{e} \\
\mathrm{S}+\mathrm{K}\end{array}$ & $\begin{array}{l}\mathrm{e} \\
\mathrm{S}+\mathrm{K}\end{array}$ & $\begin{array}{l}\mathrm{e} \\
\mathrm{S}+\mathrm{K}\end{array}$ & $\begin{array}{l}\mathrm{e} \\
\mathrm{S}+\mathrm{K}\end{array}$ & $\begin{array}{l}\mathrm{e} \\
\mathrm{S}+\mathrm{K}\end{array}$ \\
\hline $\mathrm{G}$ & & & $\mathrm{E}$ & $\begin{array}{l}E \\
S+K\end{array}$ & $\begin{array}{l}\mathrm{e} \\
\mathrm{S}+\mathrm{K}\end{array}$ & $\begin{array}{l}\mathrm{e} \\
\mathrm{S}+\mathrm{K}\end{array}$ & $\begin{array}{l}\mathrm{e} \\
\mathrm{S}+\mathrm{K}\end{array}$ & $\begin{array}{l}\mathrm{e} \\
\mathrm{S}+\mathrm{K}\end{array}$ & $\begin{array}{l}\mathrm{e} \\
\mathrm{S}+\mathrm{K}\end{array}$ & $\begin{array}{l}\mathrm{e} \\
\mathrm{S}+\mathrm{K}\end{array}$ & $\begin{array}{l}\mathrm{e} \\
\mathrm{S}+\mathrm{K}\end{array}$ & $\begin{array}{l}\mathrm{e} \\
\mathrm{S}+\mathrm{K}\end{array}$ \\
\hline $\mathrm{H}$ & & & & & & & & & & & & \\
\hline
\end{tabular}

Figure 3. Image of MTT micro-plate with 3 cytotoxic extracts

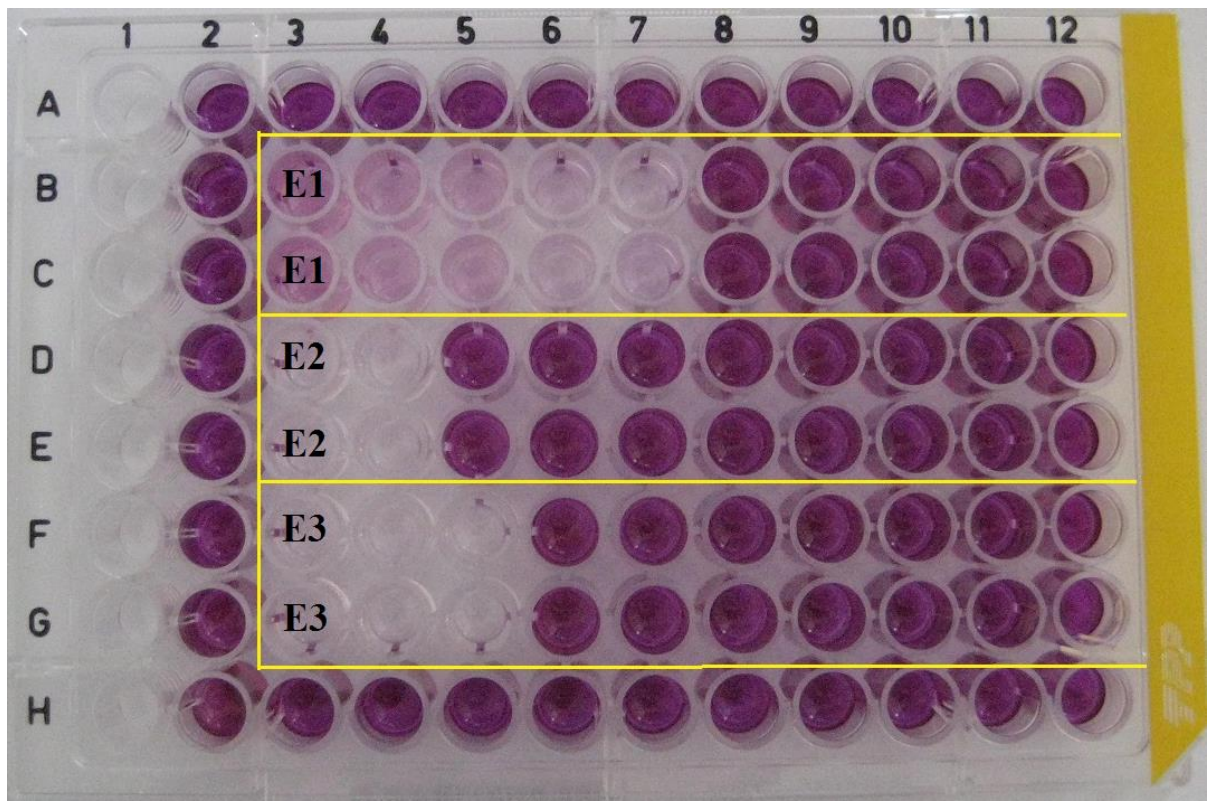


The cytotoxicity evaluation of bacterial cultures can be carried out without dilution. The cell suspension with determined density is plated on 96 -well plate and incubated for 24 hours $\left(37^{\circ} \mathrm{C}\right.$, $5 \% \mathrm{CO}_{2}, 98 \%$ humidity). After achieving the confluent culture, cells are rinsed with phosphate buffered saline (PBS) solution and then $50 \mu \mathrm{l}$ medium is added to the cell culture (Minimum Essential Medium, MEM) and $50 \mu \mathrm{l}$ of bacterial suspension prepared in the substrate adapted to the type of bacteria, e.g. Tripticase Soy Broth (TSB). Control contains, instead of bacterial suspension, $50 \mu$ l of sterile TSB medium. Each bacterial strain is tested in several replicates. After 20-hour incubation, the medium is removed together with bacteria, and MTT salt is added to the wells. After a 2-hour incubation and removal of MTT salt, $99.8 \%$ ethanol is added. Then, the absorbance is read using micro-reader and cytotoxicity is calculated from the following formula:

$\%$ cytotoxicity $=$ [1-(absorbance of

infected culture/absorbance of control) $] * 100$

\section{Own study}

Mycological and cytotoxic analysis of the following samples was performed at the Mycotoxin Analytical Laboratory, Kazimierz Wielki University in Bydgoszcz: building materials, foodstuffs, cereals, and isolates of moulds. The SK cells (swine kidney) were used to MTT test, because they are characterized by high sensitivity to the most common mycotoxins - as demonstrated by Hanelt et al. (1994). These authors compared the three cell lines were grown in monolayers: SK, $\mathrm{HeLa}$ (cells isolated from human cervical carcinoma), and MDCK cells (canine kidney) against mycotoxins. Swine kidney cells proved to be the most sensitive towards 43 analyzed mycotoxins.

The MTT test rated the cytotoxicity of the mycobiota on mouldy building walls. Table 1 presents the analysis results of samples collected from the mouldy compartments.

Table 1. The results of analyzes of building materials samples using the MTT test.

- no cytotoxicity; + low cytotoxicity; ++ moderate cytotoxicity; +++ high cytotoxicity.

\begin{tabular}{|c|c|c|c|}
\hline Sample type & Step & $\begin{array}{c}\mathrm{IC}_{50} \\
{[\mathrm{mg} / \mathrm{ml}]}\end{array}$ & Rate \\
\hline $\begin{array}{c}\text { Sample from walls from bathroom of } \\
\text { mould flat }\end{array}$ & 3 & 250 & ++ \\
\hline $\begin{array}{c}\text { Sample from walls from living room of } \\
\text { mould flat }\end{array}$ & 5 & 62.5 & +++ \\
\hline Sample from damp flat & - & - & - \\
\hline
\end{tabular}

The first two samples were taken from the walls of residential pavilions situated within the post-flood area. In both cases, there was a very high level of moulds. They showed respectively moderate and high cytotoxicity against control (Twarużek 2005). The third sample collected from mouldy tenant apartment in the city of Bydgoszcz showed no cytotoxic effects. In further detailed mycological and toxicological studies of samples it was found only the presence of mould species not producing the toxic secondary metabolites. The indoor moulds have been recognized as an important factor of air pollution. They cause adverse health effects both in humans and animals. They are also associated with an intense occupational 
exposure; high levels of exposure were recorded, among others, at farmers, hospital stuff, and at people working indoors with the faulty ventilation system (Johanning et al. 1998).
Table 2 shows the part of own studies on the contamination with moulds and assessment of cytotoxicity of food products purchased in retail trade in Bydgoszcz city.

Table 2. Analysis of food products samples using the MTT test.

- no cytotoxicity; + low cytotoxicity; ++ moderate cytotoxicity; +++ high cytotoxicity

\begin{tabular}{|c|c|c|c|c|}
\hline Sample type & Dominating mould species ${ }^{1}$ & Step & $\begin{array}{c}\mathrm{IC}_{50} \\
{[\mathrm{mg} / \mathrm{ml}]}\end{array}$ & Rate \\
\hline Raisins & 100\% Aspergillus niger & 2 & 200 & - \\
\hline Dried figs & $\begin{array}{l}\text { 57\% Aspergillus niger } \\
43 \% \text { Penicillium spp. }\end{array}$ & 2 & 200 & - \\
\hline $\begin{array}{l}\text { White powdered } \\
\text { pepper }\end{array}$ & $\begin{array}{l}\text { 44\% Aspergillus sydowi } \\
30 \% \text { Aspergillus fumigatus }\end{array}$ & 7 & 6.25 & ++ \\
\hline Ground nutmeg & 93\% Endomyces fibuliger & 9 & 1.56 & +++ \\
\hline Hot pepper & $67 \%$ Alternaria alternata & 6 & 12.5 & ++ \\
\hline $\begin{array}{l}\text { Chili pepper } \\
\text { Cayenne }\end{array}$ & 73\% Eurotium herbariorum & 10 & 0.78 & +++ \\
\hline Coffee powder & 100\% Aspergillus flavus & 6 & 12.5 & ++ \\
\hline Rye flour & $\begin{array}{l}34 \% \text { Eurotium repens } \\
25 \% \text { Penicillium }\end{array}$ & 4 & 50 & + \\
\hline Wheat bran & $\begin{array}{l}45 \% \text { Aspergillus candidus } \\
23 \% \text { Aureobasidium pullulans }\end{array}$ & 7 & 6.25 & ++ \\
\hline Buckwheat & $58 \%$ Aspergillus candidus & 5 & 25 & ++ \\
\hline Barley flakes & $\begin{array}{l}43 \% \text { Eurotium spp. } \\
42 \% \text { Cladosporium sphaerosporum }\end{array}$ & 4 & 50 & + \\
\hline $\begin{array}{c}\text { Angel hair pasta } \\
\text { made from } \\
\text { wheat flour }\end{array}$ & 78\% Aspergillus candidus & 1 & 400 & - \\
\hline Nuts & $\begin{array}{l}\text { 85\% Penicillium spp. } \\
\text { 5\% Aspergillus spp. }\end{array}$ & 4 & 150 & + \\
\hline Pistachios & $\begin{array}{l}72 \% \text { Cladosporium spp. } \\
8 \% \text { Penicillium spp. }\end{array}$ & 3 & 300 & - \\
\hline
\end{tabular}

Samples that were characterized by high mould infection were tested applying MTT (samples having lower degree of infestation were used as a control). The detection of mycotoxins in seeds or fruits brings a lot of problems and can be subject to errors due to their irregular occurrence within such raw material. The instrumental methods of analysis are not for determining the derivative forms of studied toxins and "masked" forms are completely missed, hence the MTT test was used to bio-assays (Grajewski 2003).

Several years of research performed by many authors confirm that with increasing interest in maize cultivation, the importance of this plant fungal diseases that cause a significant decline and deterioration in quality of crops, increases as well (Rataj-Gutarowska \& Frąckowiak 2006). On the basis of research, it is estimated that every year the 
diseases of maize cause losses in the yield size reaching in some years up to $30 \%$, as well as the deterioration in the quality of grain and silage mass. Mycotoxins produced by fungi colonizing mouldy maize and other raw materials can cause many human diseases (including various allergies, hormonal disorders, and cancer). In particular, their presence in the feed is a major threat to the health and life of animals (Tekiela 2008). It should be remembered that some of the mycotoxins can be ingested by humans due to the carry-over.

Table 3 shows the use of MTT test to assess the mould-contaminated wheat and maize grain as well as the by-product dried distillers grains with solubles (DDGS).

Table 3. The results of analyzes of cereal samples using MTT test.

- no cytotoxicity; + low cytotoxicity; ++ moderate cytotoxicity; +++ high cytotoxicity

\begin{tabular}{|c|c|c|c|}
\hline Type of sample & Step & $\begin{array}{c}\mathrm{IC}_{50} \\
{[\mathrm{mg} / \mathrm{ml}]}\end{array}$ & Rate \\
\hline Maize & 7 & 6.25 & ++ \\
\hline Wheat & 3 & 100 & + \\
\hline DDGS & 4 & 50 & + \\
\hline
\end{tabular}

The study of plant material again demonstrated the usefulness of the MTT test application. During many years of the research, the problem that occurred when testing the oats samples, was noted. Regardless of the degree of fungal infestation of samples (in pure material), there was the cytotoxic effect towards SK.
More detailed analysis revealed that substances found in oats - saponins and trypsin inhibitors - are characterized by toxic action (Grajewski et al. 2008).

Subsequent studies also used MTT test to assess Aspergillus genus isolates (Table 4).

Table 4. The results of the cytotoxicity analysis of Aspergillus genera isolated from air-conditioned hospital environments.

- no cytotoxicity; + low cytotoxicity; ++ moderate cytotoxicity; +++ high cytotoxicity

\begin{tabular}{|c|c|c|c|}
\hline Type of sample & Step & $\begin{array}{c}\mathrm{IC}_{50} \\
{\left[\mathrm{~cm}^{2} / \mathrm{ml}\right]}\end{array}$ & Rate \\
\hline Aspergillus ochraceus & 9 & 0.122 & +++ \\
\hline Aspergillus niger & 5 & 1.953 & ++ \\
\hline Aspergillus fumigatus & 10 & 0.061 & +++ \\
\hline Aspergillus flavus & 8 & 0.244 & +++ \\
\hline
\end{tabular}

Strains of Aspergillus genus fungi occurring in air-conditioned hospital environments were subject to cytotoxicity assessment (Table 4). In all cases, high cytotoxic potential was found (Gniadek et al. 2009). These fungi are characterized by the production of highly toxic metabolites such as aflatoxins, ochratoxin A, sterigmatocystin, and cyclopiazonic acid. In assessing the toxicity of these mycotoxins at different animal species, the nephropathic, hepatotoxic, embriotoxic, teratogenic, mutagenic, and carcinogenic influences were observed (Grajewski 2006).

\section{Summary}

Several years of own research confirmed that the cell cultures MTT test has a high sensitivity relative to moulds and their 
secondary metabolites and is a fast tool to assess their cytotoxicity. It was confirmed that due to the MTT test, it is possible to identify threats to our health, especially by mouldy or contaminated building materials or raw materials and

\section{References}

Anuszewska, E. 2010. Badanie aktywności cytotoksycznej produktów leczniczych i wyrobów medycznych. Gazeta Farmaceutyczna, 5: 36-38.

Chomiczewska, D., Kieć-Świerczyńska, M. \& Kręcisz, B. 2009. Kontaktowe zapalenie skóry z podrażnieniami. Część II Metody badania działania drażniącego substancji chemicznych. Medycyna Pracy, 60(3): 209-214.

Dzierżewicz, Z., Orchel, A., Komarska-Szostak, A., Wawszczyk, J., Węglarz, L., Szczerba, J., Wilczok, T. 2005. Aktywność biologiczna endotoksyn izolowanych ze szczepów bakterii Deusulfovibrio desulfuricans. Annales Academiae Medicae Silesiensis, 59(1): 9-16.

Gareis, M., Kuss, C. 1999. MTT-cell culture assay of pesticides. Jahresbericht BAFF, 69-70.

Gareis, M. 2006. Diagnostischer Zellkulturtest (MTT-Test) für den Nachweis von zytotoxischen Kontaminanten und Rückständen. Journal für Verbraucherschutz und Lebensmittelsicherheit., 1(4): 354-363.

Gniadek, A., Macura, A., Twarużek, M. 2009. Charakterystyka grzybów występujących w środowisku oddziału intensywnej terapii. Część 2. Cytotoksyczność wyizolowanych grzybów z rodzaju Aspergillus. Mikologia Lekarska, 16(1): 354-357.

Grajewski, J. 2003. Możliwości inaktywacji ochratoksyny A w badaniach in vitro oraz in vivo u kurcząt. Wydawnictwo $\mathrm{AB}$, Bydgoszcz, 52-53.

Grajewski, J., Twarużek, M. 2004. Zdrowotne aspekty oddziaływania grzybów pleśniowych i mikotoksyn. Alergia, 45-49.

Grajewski, J. 2006. Mikotoksyny i grzyby pleśniowe zagrożenia dla człowieka i zwierząt. Wyd. UKW, Bydgoszcz.

Grajewski, J., Twarużek, M., Miklaszewska, B., Błajet-Kosicka, A., Łukomska, W., Kosicki, R. 2008. Moulds and mycotoxins contamination of foodstuffs from retail trade in years 2006/2007. In: 30th Mycotoxin Workshop, 28-30.04.2008, Utrecht, The Netherlands, 87.

Hak, Ł. 2006. Badanie wpływu infekcji wirusem (CMV) na układ immunologiczny u chorych operowanych z powodu niedokrwienia serca. Rozprawa doktorska, Akad. Med. Gdańsk.

Hanelt, M., Gareis, M., Kollarczik, B. 1994. Cytotoxicity of mycotoxins evaluated by the finished products infected by secondary metabolites. It should be noted, however, that no single in vitro test is sufficient to consider a substance safe for human health (Chomiczewska et al. 2009).

MTT cell culture assay. Mycopathologia, 128: 164-174.

Johanning, E., Gareis, M., Yang Chin, S., Hintikka, E.-L., Nikulin, M., Jarvis, B., Dietrich, R. 1998. Toxicity screening of materials from buildings with fungal indoor air quality problems (Stachybotrys chartarum). Mycotoxin Research, 14: 60-73.

Krzysztoń-Russjan, J., Książek, I., Anuszewska, E. 2009. Porównanie użyteczności testów MTT i EZ4U stosowanych do oceny cytotoksyczności ksenobiotyków. Testy diagnostyczne, 65(6): 395-402.

Nakayama, G.R, Caton, M., Nova, M., Parandoosh, Z. 1997. Assesment of the Alamar Blue assay for cellular growth and viability in vitro. Journal of Immunological Methods, 204: 205-208.

Noatyńska, A. 2011. Oranż akrydyny - barwnik o dwóch obliczach.

http://bioinfo.mol.uj.edu.pl/articles/Naotynska03

Putnam, K.P 2002. Evaluation of eight in vitro assays for assessing the cytotoxicity of cigarette smoke condensate. Toxicology in vitro, 16: 599-607.

Rataj-Gutarowska, B., Frąckowiak, M. 2006. Grzyby patogeniczne kukurydzy z kilku miejscowości województw wielkopolskiego i dolnośląskiego w 2004 roku. Postępy w Ochronie Roślin, 46(2): 732-726.

Sajduda, A. 2007. Nowe metody wykrywania lekooporności Mycobacterium. Postępy Mikrobiologii, 46(2): 87-100.

Sikorski, Ł., Adomas, B. 2010. Biotesty w badaniach toksykologicznych i ekotoksykologicznych. Postępy Nauk Rolniczych, 4: 121-131.

Stokłosowa, S. 2004. Hodowla komórek i tkanek. Wyd. PWN, Warszawa.

Szliszka, E., Majcher, A., Domino, M., Pietsz, G., Król, W. 2007. Cytotoksyczne działanie ligandu czynnika martwicy nowotworu indukującego apoptozę (TRAIL) na komórki raka pęcherza moczowego po zastosowaniu terapii fotodynamicznej. Urologia Polska, 2007/60/2.

Tekiela, A. 2008. Fuzarioza kolb kukurydzy i skażenie ziarna przez mikotoksyny w Wielkopolsce i na Podkarpaciu. Progress in Plant Protection, 48(3): 1121-1125.

Twarużek, M. 2005. Wykorzystanie biologicznych testów (MTT i Premi Test) w ocenie skażeń pomieszczeń mieszkalnych mikotoksynami 
grzybów pleśniowych. Rozprawa doktorska, UKW Bydgoszcz.

Woźniak, A., Twarużek, M., Grajewski, J. 2004. Wykorzystanie testu kultur komórkowych (MTT) do oceny toksycznych skażeń grzybowych i mikotoksyn. In: VII Konferencja Naukowa "Mikotoksyny i patogenne pleśnie w środowisku" AB, Bydgoszcz, 25-27 .06.2004, $157-162$.

Zastempowska, E., Twarużek, M. 2016. Cytotoksyczność izolatów Trueperella pyogenes wyosobnionych $\mathrm{z}$ gruczołu mlekowego zwierząt" w sesji plakatowej. W: XXVIII Zjazd Polskiego Towarzystwa Mikrobiologów, 25-27.09.2016, Bydgoszcz.

\section{Streszczenie}

Testy biologiczne oparte na hodowlach komórkowych z powodzeniem stosowane są do oceny cytotoksyczności leków, artykułów spożywczych, pasz. Testy in vitro stają się uzupełnieniem konwencjonalnych metod chemicznych, a także alternatywą dla badań przeprowadzanych na zwierzętach. Na podstawie badań własnych można stwierdzić, że test MTT jest czułą metodą diagnostyczną przydatną w ocenie cytotoksyczności nie tylko mikotoksyn, pestycydów, bakterii, pleśni, żywności, pasz, ale także próbek uzyskanych z materiałów budowlanych. 